\title{
Fostering a Culture of Discourse in Secondary Mathematics Classrooms: Equity Approaches in Teaching and Teacher Education for Emergent Bilingual Students
}

\author{
Hacia una Cultura Discursiva en el Salón de Clases de \\ Matemáticas en la Secundaria: Capacitación Docente para la \\ Equidad en la Enseñanza de Estudiantes Bilingües Emergentes
}

\section{Para uma Cultura Discursiva em Aulas de Matemáticas na Secundária: Capacitação Docente para a Equidade no Ensino de Estudantes Bilíngues Emergentes}

Cristian Aquino-Sterling ${ }^{1 *}$ Fernando Rodríguez-Valls ${ }^{2}$ William Zahner ${ }^{1}$

${ }^{1}$ San Diego State University ${ }^{2}$ California State University

\begin{abstract}
The continued proliferation of linguistic diversity in US mainstream classrooms, coupled with the language demands of the Common Core State Standards for mathematics instruction (CCSSM), and the National Council of Teachers of Mathematics' Principles to Actions (PtA), has prompted educational researchers to identify effective, linguistically relevant practices for preparing secondary mathematics educators adept at meeting the needs of emergent bilingual students. In this article we argue for implementation of teacher education courses in mathematics that infuse "pedagogical language knowledge" as a tool for providing future teachers the skills and dispositions to foster a "classroom culture of discourse." This call come in light of the discipline-specific language demands of the above-mentioned standards and secondary students' use of variable linguistic repertoires across and within languages to learn and display mathematical thinking and ideas.
\end{abstract}

Keywords: Teacher education, Emergent bilingual students, Pedagogical Language knowledge, Equity, Social justice.

La proliferación de la diversidad en los salones de clase en EEUU, unida a las exigencias lingüísticas de los denominados Common Core State Standards for Mathematics y de los estándares Principles to Actions (PtA) del Concilio Nacional de Maestros de Matemáticas, ha motivado a los investigadores en el campo de la educación a que identifiquen prácticas educativas orientadas a la preparación de una nueva generación de maestros de matemáticas aptos para diseñar e implementar un modelo pedagógico equitativo que responda a las necesidades del estudiantado bilingüe emergente. Por ende, en este artículo recalcamos la importancia de impartir cursos de formación docente en matemáticas que potencien un

*Contacto: caquino@mail.sdsu.edu

ISSN: 2254-3139

www.rinace.net/riejs/

revistas.uam.es/riejs
Recibido: $\quad 16$ de septiembre 2016

$1{ }^{\text {a }}$ Evaluación: 10 de octubre 2016

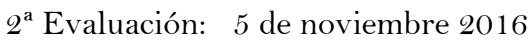

Aceptado: 23 de noviembre 2016 
conocimiento de lo que se ha denominado en inglés como pedagogical language knowledge. Estos conocimientos servirán como herramientas que asistirán a dichos maestros a fomentar una cultura inclusiva y discursiva en el salón de clase a raíz de las exigencias lingüísticas de los nuevos estándares y de la variación lingüística que caracteriza al contexto escolar.

Palabras claves: Formación docente, Bilingües emergentes, Conocimiento pedagogico del lenguaje, Equidad, Justicia social.

A proliferação da diversidade em salas de aulas em EEUU, unida as exigências linguísticas dos denominados Common Core State Standards for Mathematics e das normas do Principles to Action (PtA) do Concilio Nacional de Maestros de Matemáticas, têm motivado aos investigadores no campo da educação a que identifiquem práticas educativas orientadas à preparação de uma nova geração de professores de matemáticas aptos a desenvolverem e implementarem um modelo pedagógico equitativo que responda as necessidades dos estudantes bilíngues emergentes. Portanto, neste artigo enfatizamos a importância de promover cursos de formação docente em matemáticas que potencialize um conhecimento denominado em inglês como pedagogical language knowledge. Estes conhecimentos servirão como ferramentas que auxiliarão a estes maestros a fomentarem uma cultura inclusiva e discursiva em salas de aulas a raiz de exigências linguísticas dos novos padrões e da variação linguística que caracteriza o contexto escolar.

Palavras-chave: Formação docente, Bilíngues emergentes, Conhecimento pedagógico da linguagem, Equidade, Justiça social.

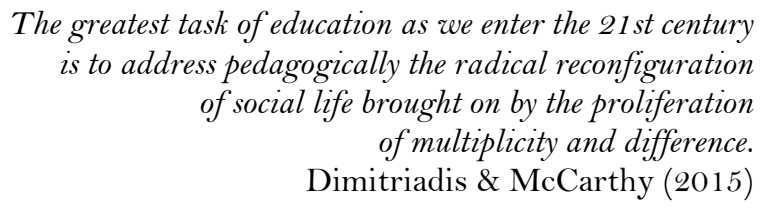

\section{Introduction}

Patterns of immigration and changes in school populations in Europe, Australia, and North America, and postcolonial school systems have prompted educators to examine how we can meet needs of linguistically diverse groups of students more effectively. In the US, the growth in the emergent bilingual student demographic has coincided with the adoption of new content standards in mathematics and English Language Arts (ELA) called the Common Core State Standards (CCSS). These standards place significant emphasis on the need for all students to develop language and disciplinary literacies across the content areas as they engage in complex discourse processes.

Since the launching of the CCSS initiative in 2009, there has been steady production of research focused on the essential knowledge and skills K-12 teachers need to acquire in order to meet the academic needs of all students, particularly those of the growing emergent bilingual student population (Bunch, 2013; Bunch, Kibler and Pimentel, 2013; Council of Chief State School Officers, 2012; Crespo, 2016; Delpit, 2012; Hakuta, 2013; Lee, Quinn and Valdés, 2013; Liquanti and Hakuta, 2012; Moschkovich, 1999, 2007, 2012, 2016; Quinn, Lee and Valdés, 2012; Rodríguez and Kitchen, 2005; Téllez, Moschkovich, and Civil, 2011; Understanding Language Initiative, 2012; van Lier and Walqui, 2012; White, Crespo and Civil, 2016; Zahner and Moschkovich, 2011). Within this line of research, notable scholars in the field of mathematics education have begun 
to address the implications of the Common Core State Standards for Mathematics (CCSSM) for teaching and learning in linguistically diverse classroom contexts (Moschkovich, 2012). Given the emphasis on the performance of complex language made explicit in the CCSSM, as well as other standards influencing the teaching of mathematics in secondary schools (e.g., National Council of Teachers of Mathematics, 2014), educators are called to envision new ways to orchestrate instruction in order to help their students acquire the knowledge and language skills needed to engage in meaningful disciplinary discourse practices (Fang and Schleppegrell, 2010; Moje, 2011; Shanahan and Shanahan, 2008).

However, as explicit in the research literature, mathematics educators primarily view themselves as content-area teachers not responsible for promoting language development in their classrooms (Constantino, 1994; de Jong and Harper 2008; Roepke and Gallagher, 2015; Tan, 2011). These understandings, coupled with CCSS requirement that all students develop discipline-specific ways of thinking and communicating (van Lier and Walqui, 2012), have created an imperative in the field of mathematics teacher education to continue to identify curricular and pedagogical approaches that facilitate the practice of linguistically relevant teacher education in light of the "linguistic turn" in standards-based reform. In other words, it is now our responsibility to offer teacher education courses where future content-area educators learn to facilitate the development of language and literacies relevant to their disciplines.

This effort would require teachers to learn to address the technical aspects of planning standards-based disciplinary language and literacy activities by, for example, (a) identifying language demands in secondary mathematics standards, (b) formulating relevant content and language objectives, and (c) providing language scaffolds (sentence and/or discourse frames) to support student learning (we exemplify this process in figure 1) and help them engage with language in extended ways, beyond the sentencelevel of performance (Aquino-Sterling, 2014).

Although we recognize these as important skills future mathematics teachers must acquire to facilitate the use of discipline-specific discourse practices in secondary school classrooms, beyond these technical understandings, we argue that it is also important for future mathematics teachers to learn how to promote and foster a "classroom culture of discourse" in light of the linguistic diversity we find in contemporary classrooms (Quinn et al., 2012). Linguistic diversity incorporates not only different languages (e.g., English and Spanish) but also different language varieties (e.g., Chicano Spanish, African American Vernacular English), and modalities (speaking bilingually or 'codeswitching,' 'translanguaging'). In order to conduct this work in linguistically diverse classrooms, it is imperative teachers acquire pedagogical language knowledge (Bunch, 2013; Galguera, 2011), a concept defined and operationalized below.

\section{The relevance of social justice}

In our work, we conceptualize social justice as an orientation to education that aims at providing all students with equal opportunity to learn, while also acknowledging, valuing, and validating the identities, life experiences, and perspectives of all students regardless of their language, race, ethnicity, social class, sexual orientation, and ability. As Freire indicates: 
What I have been proposing [...] is a profound respect for the cultural identity of students - a cultural identity that implies respect for the language of the other, the color of the other, the gender of the other, the class of the other, the sexual orientation of the other, the intellectual capacity of the other; that implies the ability to stimulate the creativity of the other. (cited in McLaren, 2000, p. 139)

Our focus on mathematical language/discourse practices is paramount for such a social justice orientation because language is one important medium through which equity and inequities are structured and sustained within classroom contexts (Wagner, HerbelEisemann and Choppin, 2012). If middle and high school students are to become thoughtful and socially aware mathematicians, teachers must create democratic, participatory, and inclusive learning opportunities where students acquire mathematical discourse. As Bennett (2014) explains, this discourse "includes an element of debate and is an interactive, dynamic and inclusive strategy with the intent of developing particular mathematical concepts of practices" (p. 21). Furthermore, secondary mathematics teachers' knowledge, skills, and orientations for fostering a "classroom culture of discourse" (Quinn et al., 2012) in secondary mathematics classrooms is a matter of social justice as teachers' use of language "affect[s] the equality, or inequality, of students' educational opportunities” (Cazden, 2001, p. 3).

\section{Standard:}

1. NGSS - HS-LS2-2. Use mathematical representations to support and revise explanations based on evidence about factors affecting biodiversity and populations in ecosystems of different scales.

\section{Content Objectives:}

1. Students will learn to use multiple data sets in order to make mathematical representations of data.

2. Students will use appropriate mathematical representations (e.g. box and whisker plot) in order to illustrate key features of data sets.

3. Students will identify factors affecting biodiversity.

\section{Language Objectives:}

1. Students will support and/or revise explanations on factors affecting biodiversity.

2. Students will employ the following sentence frames to support and/or revise explanations:

a. Under condition $\mathrm{X}, \mathrm{Z}$ is a valid explanation given that first and second

b. Based on it could be said that is not a valid explanation because the evidence refutes the idea that

Figure 1. Standard, content objetives and language objetives Note: Elaborated by the authors. 
With respect to emergent bilinguals", an important caveat made in the "Framework for English Language Proficiency Development Standards Corresponding to the Common Core State Standards and the Next Generation Science Standards" (CCSSO, 2012) indicates, "[the] changes [in CCSS] also entail a reconceptualization of the way [emergent bilinguals] 'apprentice' into these demanding disciplinary practices by simultaneously acquiring and developing language as well as acquiring disciplinary knowledge and skills" (p. 1). Hakuta (2015) goes even further to suggest that "[u $]$ nder the new standards, learning academic content has become inseparable from an English language development class" (p. 25). The importance attributed to language and discourse in the new standards calls for a new classroom dynamic where mathematics teachers are to be mindful that EBs are doing "double the work" (Short and Fitzsimmons, 2007). In terms of accountability, this double work "requires that emergent bilinguals show continual progress on academic content assessments in English as well as on English language proficiency assessments" (Menken, 2012, p. 442). As such, Us educators are called to implement evidence-based strategies for supporting emergent bilingual students in the often-challenging process of learning content through language and language through content in high school classrooms (Goldenberg, 2008).

As teacher-scholars responsible for preparing pre-service content-area teachers to work with linguistically diverse and emergent bilingual student populations in the era of new standards, we are committed to designing and implementing curriculum aimed at providing future teachers with the knowledge and skills needed "to define and facilitate a classroom culture of discourse" (Quinn et al, 2012, p. 3). However, from the perspective of equity and social justice, we here affirm and promote that this approach should extend beyond just "accepting [students'] contributions for their meaning and their values in the discourse however flawed or informal [their language]” (Quinn et al, 2012, p. 3).

In our view, fostering a "classroom culture of discourse" needs to acknowledge the inherent linguistic value of discourse practices that historically have been socially stigmatized and deemed "incorrect." In other words, fostering a truly inclusive and democratic culture of discourse in mathematics classrooms requires secondary teachers to challenge deficit views of language and affirm and validate the often marginalized hybrid and/or vernacular language practices emergent bilingual students tend to enact and display (Aguirre, 2016; García and Kleyn, 2016; Nero and Ahmad, 2014). Within this approach, students have the right to employ their own language(s), language varieties, and/or modalities to engage and perform academic tasks. In other words, complex discourse practices in mathematics need not be confined to the logics of the "monoglot 'standard" (Silverstein, 1996). However, at the same time, emergent bilingual students do have the right to engage in activities that provide opportunities for expanding their (disciplinary) language competencies. In this way, mathematics teacher preparation programs are called to equip future teachers with the knowledge and orientations needed to design instruction that foster the continued development of students' "repertoire of complex linguistic resources" (Valdés, 2015, p. 268). Via this approach, teachers will be able to orchestrate safe classroom spaces where high school

\footnotetext{
${ }^{1}$ Instead of the limiting and incomplete "English Learners" (ELs) label, we employ the label "Emergent Bilinguals" (EBs). We also substitute ELs for EBs in direct quotes.
} 
students, and particularly emergent bilinguals, can freely function as autonomous linguistic agents, free to engage in multiple 'ways with words' and to embody and enact multiple linguistic and disciplinary identities across languages, language varieties, and modalities. As Pennycook (2003) observes " $[i]$ t is not that people use language varieties because of who they are, but rather that we perform who we are by (among other things) using varieties of language" (p. 258).

The use of non-dominant and so-called "non-standard" forms should not be at the service of just learning "standard" varieties, but should hold equal weight within the social context of the classroom, serving thus as a conscious practice of resistance to dominant language ideologies that continue to promote deficit views of the language of the other. Moreover, as advocates for content-area classrooms that exhibit a focus on discourse, we understand that it is not the role of content-area teachers to function as "language teachers" per se, but rather as practitioners who ably orchestrate relevant activities aimed at socializing their students into the discursive performances and cognitive moves characteristic of their respective disciplinary communities of practice (Duff, 2010; Duff and Talmy, 2011; Quinn et al., 2012; Wenger, 1999).

Given the new dynamics of teaching and learning in K-12 discourse-intensive classrooms, in the present work we provide a general analysis of the language and literacy demands of the CCSSM and the PtA framework. We argue that given the continued proliferation linguistic diversity across and within languages, fostering a culture of discourse in secondary mathematics classrooms needs to be embedded within a framework for linguistic equity and social justice. Diverse student voices, including the voices articulated via socially stigmatized language varieties (Baugh, 1999; Zentella, 1997), must be encouraged, validated, and employed in their own right and as a bridges for helping students engage in formal discourse practices also relevant to learning and thinking like mathematicians.

\section{The role of pedagogical language knowledge}

Since the development of Shulman's (1986) concept of pedagogical content knowledge, there has been an emergence of various forms of "pedagogical knowledge" teachers must acquire. The knowledge and skills mathematics teachers require to work effectively with emergent bilingual students is intimately related to what Galguera (2011) and Bunch (2013) have conceived as pedagogical language knowledge. Bunch (2013) defines the concept as "knowledge of language directly related to disciplinary teaching and learning and situated in the particular (and multiple) contexts in which teaching and learning take place" (p. 307). Bunch (2013) argues that:

[...] efforts to prepare teachers for working with [emergent bilinguals] to engage
with increasing language and literacy expectations across the curriculum requires
development of pedagogical language knowledge (Galguera, 2011) - not to "teach
English" in the way that most mainstream teachers may initially conceive of (and
resist) the notion, but rather to purposefully enact opportunities for the development
of language and literacy in and through teaching the core curricular content...(p.
298)

Moreover, as Galguera (cited in Bunch, 2013) indicates, working from a pedagogical language knowledge framework entails acquiring a critical awareness of language (Alim, 2005). From this perspective, all languages and language varieties can always serve as a 
resource to help students engage in mathematics language practices while meeting the language and literacy demands of new standards irrespective of the social power these hold. Ultimately, working from a critical language awareness perspective requires the development of a consciousness about how opportunities to learn are distributed among students of different economic, ethnic, racial, and linguistic backgrounds (Sommerfeld and Cobb, 2006).

In our view, pedagogical language knowledge would help mathematics teachers deconstruct the "problematic beliefs" prospective mathematics teachers tend to hold regarding students who are bilingual or learning English. Moschkovich (2016) has identified, namely: (a) "English learners [or emergent bilingual students] cannot participate in mathematical discussions;" (b) "Everyday or home languages are obstacles to doing and learning mathematics," and (c) "Mathematical discourse requires formal vocabulary to express mathematical ideas" (p. 162).

Yet, given the language and disciplinary literacy demands of the CCSS (Aquino-Sterling, 2014; Manderino and Wickens, 2014), pedagogical language knowledge (Bunch, 2013; Galguera, 2011) would also serve as a tool for helping future mathematics teachers facilitate a "classroom culture of discourse" (Quinn et al., 2012) where emergent bilingual students expand their linguistic repertoires to display multiple and new ways of thinking like "expert" mathematicians. As previously indicated, we consider that it is the role of the mathematics educator not only to validate and promote the home and community-based language practices of their students, including their translanguaging (García and Kleyn, 2016) and use of vernacular forms of language (Nero and Ahmad, 2014), but also to acquire research-based understandings for designing and facilitating effective classroom lessons that promote the continued expansion of emergent bilingual students' language and disciplinary literacy competencies.

\section{Defining discourse}

Although the term discourse "has perhaps the widest range of possible significations of any term in literary or cultural theory" (Mills, 2004, p. 1), in this article, we understand the concept in two fundamental ways. First, as "a linguistic unit [...] larger than a sentence;" "a formal and orderly and usually extended expression of thought on a subject;" and as "connected speech or writing" (Merriam-Webster, our emphasis). Second, we understand it as a mode of being and acting in the world mediated through language; what Gee (2007) defines as "capital D" Discourses, or ways of "acting- interactingfeeling- emoting- valuing- gesturing- posturing- dressing- thinking- believingknowing- speaking- listening" (p. 33). Both the language and disciplinary knowledge and skills high school students are called to acquire, as made explicit in the CCssM, point to the two aspects of discourse defined above: through extended expressions of thought, students begin to take on and perform disciplinary identities, thus becoming members of academic communities of practice. The content-area teachers' role is to facilitate these processes in order to socialize students into disciplinary ways of constructing, expressing, and applying knowledge (Spires, Kerkhoff, and Graham, 2016).

It is through their use and display of a wide range of discursive practices -the performance of extended language structures- that high school mathematics students take on disciplinary identities and become members of academic communities of practice 
(Duff, 2010; Duff and Talmy, 2011; Wenger, 1999). The language in the CCSSM call for teachers to collaborate with students to co-construct a culture of discourse in the classrooms and to express their thinking and knowledge by means of extended and complex discourse performances (Aquino-Sterling, 2014). However, as teacher educators concerned with equity and social justice in mathematics classrooms, we must pay particular attention to the impact social, mathematical, scientific, cultural, and political aspects of classroom interaction have on students' opportunities to participate in "privileged" discourse practices; those that would "provide access to future resources" (Wagner et al., 2012, p. 4).

Fostering a culture of discourse in mathematics classrooms requires educators acknowledge and validate diverse uses of language in the classroom, while at the same time creating opportunities for students to engage in linguistic exchanges proper of formal academic and disciplinary contexts. In terms of acknowledging and validating the linguistic capital emergent bilingual students bring to the classroom, teachers must create activities that promote and endorse the idea of critical literacy (Freire, 1970). As Gutsein (2005) explains, students learning mathematics should "become critically literate... to examine one's own and others' lives in relationship to sociopolitical and cultural-historical contexts" (p. 5). In this context, teachers and students could work in activities such as the one proposed by Xiong (n.d.). In these activities, students and teachers "explore students' family constellations to examine numbers and operations [...] by asking specific questions regarding the languages spoken among family members" (n.p.). The goal of these activities is to empower students to read and write the world with mathematical and critical eyes. Yet, equally important is to expand the linguistic funds of mathematical knowledge students and families possess (Civil, 2002; González, Andrade, Civil, and Moll, 2001). In this sense, mathematics teachers in secondary schools should model for their student's discipline-specific discourse practices (e.g., how to write a proof when solving a problem; how to use discipline-specific vocabulary when explaining thinking process; how to convert formulas into written texts).

\section{The demand for a "classroom culture of discourse"}

The emphasis on the importance of mathematical communication and the value of disciplinary forms of expression in mathematics classrooms is not new. In Principles and Standards for School Mathematics (NCTM, 2000), made explicit various "Communication Standards" relevant to $\mathrm{P}-12$ education. NCTM determined:

[i]nstructional programs from prekindergarten through grade 12 should enable all
students to (1) organize and consolidate their mathematical thinking through
communication; (2) communicate their mathematical thinking coherently and clearly
to peers, teachers, and others; (3) analyze and evaluate the mathematical thinking
and strategies of others; and (4) use the language of mathematics to express
mathematical ideas precisely. (p. 348$)$

These communication standards highlight how developing mathematical language moves beyond learning technical words. These standards also illustrate the range of purposes for using language in the classroom. Standards 1 and 2 highlight the functions of communicating to learn, and 3 and 4 are related to using mathematical knowledge to evaluate thinking or strategize and to express ideas (Wells and Wells, 1984). 
Standards 2 and 4, in particular, point to the idea of developing discourse practices, both at the level of "extended expression of thought" and "connected speech" (2), and at the level of disciplinary discourse practices (4). Standard 2, for example, refers to the level of engaging in extended and connected discourse practices as students are called to express "mathematical thinking coherently and clearly." In Standard 4, high school students are called to "use the language of mathematics" to communicate their ideas. In this sense, "as students develop clearer and more-coherent communication (using verbal explanations...) they become better mathematical thinkers" (NCTM, 2000, p. 348).

In the new era of Common Core State Standards, we find a special focus on three areas of concern regarding language: (1) language as a key contributor to the requirements in all subjects; (2) the development of communicative and academic language skills within English Language Arts and across subject areas; and (3) knowledge of language, linguistic conventions, and vocabulary acquisition (van Lier and Walqui, 2012, p. 2). The CCsSM, in particular, are framed by eight "Standards for Mathematical Practice" (SMP), two of which can be considered as discourse-intensive/related practices, namely (SMP3): Construct viable arguments and critique the reasoning of others; and SMP6: Attend to precision (National Governors Association, 2010).

MP3 requires students "compare the effectiveness of two plausible arguments, distinguish correct logic or reasoning from that which is flawed, and -if there is a flaw in an argument- explain what it is." Furthermore, students should be able to " $[\ldots]$ listen or read the arguments of others, decide whether they make sense, and ask useful questions to clarify or improve the arguments." In SMP3 we find requirements to employ both receptive (listen; read) and productive (compare; explain; ask) language skills. Attending to precision (SMP6) refers to how mathematically proficient students should "try to communicate precisely to others" and "to use clear definitions in discussion with others and in their own reasoning." By the time students are in high school, students are expected to "have learned to examine claims and make explicit use of definitions." Both SMP3 and SMP6 explicitly highlight how students are expected to begin using mathematical language in the service of learning.

The appearance of the CCSSM prompted NCTM's publication of another landmark document, Principles to Actions (NCTM, 2014), the latter being in clear alignment with CCSSM. PtA describes the teaching practices that align with the content and practice demands of the CCSSM. The teaching practices highlighted in PtA are:

- Establish mathematics goals to focus learning.

- Implement tasks that promote reasoning and problem solving.

- Use and connect mathematical representations.

- Facilitate meaningful mathematical discourse.

- Pose purposeful questions.

- Build procedural fluency from conceptual understanding.

- Support productive struggle in learning mathematics.

- Elicit and use evidence of student thinking.

Just as the SMP in the CCSSM require students to use academic language and engage in disciplinary discourse practices, the MTP in PtA guide secondary teachers to use complex 
academic language and to help students develop these competencies. MTP 4, 5, and 8 are the most clearly linked to the pedagogical uses of language. For example, posing purposeful questions (MTP5) typically happens in whole class and small group verbal interaction, and a teacher who poses purposeful questions must consider both the form of the question and the expected form of the response. Additionally, MTP 1, 2, and 3 all indirectly require teachers to be intentional in the development of academic language. For example, the mathematics goals of a lesson that focuses on developing conceptual understanding must require some kind of communication that will provide evidence of conceptual understanding.

As we have described, the $P a S$, CCSSM, and PtA frameworks demand the use of complex discourse practices on the part of the student and the teacher. For educators of emergent bilingual students who focus on equity and social justice, these standards and guidelines also create opportunities where mathematics educators seize the opportunity to define and facilitate a classroom context where students employ varied linguistic repertoires to perform disciplinary discourse tasks in "extended expressions of thought on a subject" to learn and to do mathematics. This can be accomplished via the practice of "participatory discourse" which emerges when teacher and students exchange communicative actions that end in a consensus that will develop a cognitive interest in the content being taught (Rodríguez-Valls, 2009).

In the following, we provide two classroom examples that illustrate how the ideas developed thus far can be operationalized. The first example is a re-analysis of a classroom interaction described in Moschkovich (1999). In this bilingual third grade classroom the teacher and students co-constructed key mathematical concepts through engaging in extended dialogue. This example illustrates both the CCSSM practices in action as well as the teaching practices described in PtA. The second example, from Zahner and Willey (2014), illustrates how these ideas might look slightly different in linguistically diverse secondary classrooms. In both cases, we see how grade-level mathematics was used for developing language among emergent bilingual students.

\section{Classroom examples}

\subsection{Mathematical-pedagogical language in an elementary geometry lesson}

Our first illustration of fostering a "classroom culture of discourse" and the workings of pedagogical language knowledge as implicated in the SMP and MTP comes from Moschkovich (1999), which describes a whole class discussion in a bilingual third grade classroom. During the discussion, emergent bilingual students were learning to classify quadrilaterals and the students used cutouts from a tangram to support their communication. It is important to note that this lesson was an introduction to reasoning about polygon properties, and the relationships among quadrilaterals can be complicated. For example, all squares are rectangles, but the converse is not true. This introductory lesson links to the CCSSM Practice Standards because students were asked to justify claims (SMP3) and use language precisely (SMP6). This lesson also sets the stage for the 5th grade content standard "Classify two-dimensional figures into categories based on their properties" (CCSSM Standard 5.G.B.3). Moschkovich (1999) used several extended transcripts to illustrate how several emergent bilingual students offered observations and made generalizations about quadrilaterals. Yet, given the 
complexity of the topic and the students' level of development of academic English, the students' talk was often incomplete and did not conform to conventional English usage. However, Moschkovich notes that rather than correct the students' grammatical errors, the teacher posed purposeful questions (MTP5), used multiple representations (MTP3), and identified and highlighted kernels of important mathematical ideas in the students' talk (MTP4 and MTP8). These practices identified by Moschkovich (1999) are also found in the mathematical teaching practices in PtA. Posing purposeful questions is MTP5. Using multiple representations is (MTP3). Finally, Building on students' ideas relates to MTP4 and MTP8.

To illustrate this further, we include one excerpt of a whole class discussion from Moschkovich (1999, pp. 13-16):

14. T: What were you going to say, Betsy?

15. Betsy: Also a parallelogram it calls a rectangle.

16. T: A parallelogram is also a rectangle? They can be both?

17. Betsy: Yeah.

18. T: Wow, very interesting. Can you convince me that they can be both?

19. Betsy: Because a rectangle has four sides and a parallelogram has four sides.

20. T: [unclear]

21. Eric: [unclear] a parallelogram.

22. T: You want to borrow one? [a tangram piece] I really want to remind you that you really have to listen while your classmate is talking ...

23. Eric: Because these sides [runs his fingers along the widths of the rectangle] will never meet even though they get bigger, and these sides [runs his fingers along the lengths of the rectangle] will never meet even though they get bigger. And these sides [picks up a square] will never meet [runs his hand along two parallel sides] and these sides will never meet. [runs his hand along the other two parallel sides]

24. T: When you say get bigger you mean if we kept going with the line? [gestures to the right with his hand]

25. Eric: Yeah.

26. T: Very interesting.

In her analysis of this exchange, Moschkovich (1999) highlights three practices used by this teacher: (1) he prompted student talk, including from emergent bilingual students who were still acquiring academic English (e.g., lines 14, 18, and 22); (2) he responded to his students' mathematical ideas rather than the grammatical form of the answer (e.g., lines 16 and 24); and (3) he used discourse moves such as "re-voicing" to simultaneously give students credit for volunteering ideas and to rephrase the student language in terms that were more aligned with standard mathematical phrasing (e.g., lines 16 and 24).

Connecting directly to the theoretical perspective we develop in this paper, this excerpt illustrates the strategic use of language by the teacher in order to teach content and promote valued discourse practices in the CCSSM. For example, by asking Betsy to convince him that a quadrilateral can be both a parallelogram and a rectangle, the teacher prompted Betsy and her classmates to produce an argument (SMP3) and attend to the precision of her claim (SMP6). 


\subsection{A Discourse-worthy task from secondary mathematics}

This same interweaving of mathematics content and discourse practices as exemplified in Moschkovich (1999) can occur at the secondary level. Zahner (2015) describes a lesson in which a ninth grade algebra teacher, Ms. V., in a school with over $30 \%$ emergent bilingual students used a non-routine puzzle problem to introduce technical mathematical terminology. In this lesson the teacher was introducing a "problem of the week" with the goal of modeling the process of setting up and solving a non-routine problem. This related to the Common Core's first Standard for Mathematical Practice.

The problem, called the "Haybaler Problem," describes a situation in which five bales of hay were weighed in pairs. Students are given a list of ten distinct weights and their task is to find the weight of each bale of hay (Fendel, Resek, and Alper, 1996). While the problem itself was not linked to particular content standards in the textbook, embedded in the problem are important mathematical procedures and concepts including systematically counting combinations (a topic related to 7.SP.C.8.B and foundational for HSS.CP.B.9 where permutations and combinations are formalized) and using properties of operations to justify arguments (SMP3). The Haybaler problem can also be solved using systems of equations (8.EE.C.8 and 9-12.REI.C.6) or matrices (9-12.REI.C.8), although these are not necessarily the optimal tools to use for this problem.

Ms. V. introduced the Haybaler problem by asking her students to read the problem aloud in both Spanish and English. After reading the problem, Ms. V. asked her students what the problem was about. One student said "bales" and Ms. V. responded "I don't know what a bale is. Do you? Talk to your groupmates, what is this problem about?" After about a minute of group discussion Ms. V.'s students clarified the meaning of the term "bale" and turned their attention to the puzzle. Perhaps notable in this brief exchange was that Ms. V. recognized that "bale" might be unfamiliar to some students, and she allowed a short amount of time for students to clarify the meaning of this nonessential term with classmates.

The way Ms. V. introduced "bale" contrasts sharply with how she introduced the academic term "commutative property." After launching the problem and clarifying the meaning of bales, Ms. V. instructed the students to try and solve a simpler problem: given four weights, they were to write all possible combinations of four bales labeled A, $\mathrm{B}, \mathrm{C}$, and D. As might be expected, some students struggled to list all of the pairs systematically. However, Ms. V. did not correct student errors. Instead, she allowed an opportunity for technical terminology to emerge as students wrote combinations on the board:

Ms. V.: Who wrote D plus B? [referring to the sum $26+32]$ Hector? Is that the same and B plus D [referring to the sum $32+26]$ ?

Krystal: Yes.

Ms. V.: Yes, Why?

Krystal: Because adding you could do it either way.

Ms. V.: What's that called when you're adding them and you can do it either way?

Multiple Students: Distributive.

Susana: Commutative. 


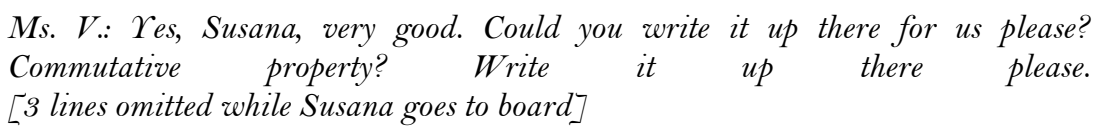

Ms. V: OK can you go up there where it says D plus B. And write twenty-six plus thirty two underneath twenty-six plus thirty-two equals fifty-eight and then right next to it write commutative C-O-M-M-U-T-A-T-I-V-E (Ms. V. says this as Susana writes on the board). OK commutative. OK good. Thank you so let's give Susana a big round of applause.

Ms. V.'s Lesson on the Hayblaer problem primarily targeted the Common Core Standards for Mathematics Practice (e.g., SMP1 and SMP4). At the same time this lesson also targeted important content standards related to permutations and combinations. This focus on key mathematical ideas illustrates how Ms. V. enacted SMP1 of establishing goals to focus learning.

Ms. V.'s treatment of the terms "bale" and "commutative property" also illustrates how Ms. V. was purposeful in her use of questioning (MTP5) and conducting a discussion (MTP4). For example, Ms. V. anticipated that her students would need to define the unfamiliar term "bale," but Ms. V. did not use too much time on this non-essential term. Instead, she asked the students to clarify the context for about a minute, and then moved on once she was satisfied that students understood the "cover story." In contrast with "bale," the term "the commutative property" is a key property of operations that is used in mathematics curriculum materials and assessments. Ms. V. was aware of the importance of this term. Thus, it is interesting to note how Ms. V. introduced this term to her class. Rather than "pre-teach" vocabulary, Ms. V. set up a problem situation where the need for the term would emerge naturally, and then highlighted the use of the term in context.

\section{Framing classroom discourse}

Teacher education programs face a new set of demands with the implementation of the CSSSM in secondary schools. It is imperative pre-service mathematics teachers acquire tools such as pedagogical language knowledge (Bunch, 2013; Galguera, 2011), to effectively teach emergent bilingual students the discourse practices and cognitive moves characterizing knowledge construction in mathematics. As Freeman and Freeman (2015) underscore, "teachers need to have the knowledge of how academic language of their discipline works and should be prepared to help their students read, write and discuss that content" (p. xi). Academic language, within this context, is aligned and contextualized by the content-area literacies (e.g., mathematical). At the same time, it is imperative teachers encourage and promote a "classroom culture of discourse" that validates the diverse language practices of emergent bilinguals.

Beyond the discourse demands of the new standards, math teachers must scaffold and develop a discourse that will prepare students to become critical learners when analyzing and discussing mathematics. Discourse within this context becomes a practice of analyzing, discussing and presenting ideas with critical eyes (Giroux, 2001). Teachers and students must reach an agreement on the meaning of both social justice and equity as these relate to mathematics. In our eyes, and aligned with the statement made by the National Council of Supervisors of Mathematics and TODOS (2016), mathematics must: 1) promote additive models in teaching and learning, 2) be the springboard for academic achievement, 3) engage teachers and students in critical dialogues and 4) support 
culturally and linguistically inclusive and responsive education for all emergent bilingual students.

A culture of discourse in the inclusive classroom for emergent bilingual students is defined by two main ideas: a) engaged pedagogy, and b) culturally and linguistically responsive methodology. An engaged pedagogy, as hooks (2010) explains, "functions more like a cooperative where everyone contributes to make sure all resources are being used, to ensure the optimal well-being of everyone" (p. 22). The "engaged pedagogue" builds a sense of caring and respect by using academic language that nourishes the intellectual development of both students and teachers. Incorporating and valuing all the linguistic registers students bring to the classroom reinforces that engagement.

In the same way, a culturally and linguistically responsive approach to mathematics education within linguistically diverse classroom contexts seamlessly builds bridges between the way emergent bilingual students talk and the discipline-specific ways with words students must learn in order to engage the discipline in deeper, expert ways. As Gibbons (2009) illustrates when describing a science lesson on magnets, science teachers could use the phrase "getting together" before introducing the word attract. Once the word attract is introduced, science teachers could further reinforce, with Spanish, French and Italian speaking students, the idea of cognates attract/artier (Spanish), attract/attire (French) and attract/atrarrare (Italian). In this context, teachers make use of their pedagogical language knowledge to help students comprehend and use new academic concepts that build on each other. Using a bilingual pedagogy help teachers and students link languages, which helps to reinforce students' understanding of the specialized subject matter language (Beaudrie, 2015). In addition, deeper understanding of the subject matter calls for integrating language as the content is being explained and examined by students and teachers (Aalto and Tarnanen, 2015).

Given the above, secondary mathematics teachers must be well prepared to integrate language development activities while teaching content knowledge. When teachers acquire pedagogical language knowledge, they are able to facilitate dialogic interactions between peers, peers and teachers, and both groups with texts, videos, audio (music), and interactive images (art). These interactions occur within the Zone of Cultural Comfort (ZCC) where "knowledgeable others" support $(+1)$, validate and learn from their peers by providing various forms of scaffolding. It is in ZCC where pedagogical language knowledge is cooperatively constructed through multimodal learning along the content continuum (Sankey and St. Hill, 2009).

When mainstream mathematics teachers work from a pedagogical language knowledge approach, and with a concern for equity and social justice, they create activities that value and validate the often-marginalized voices of emergent bilingual students. Where once a lecturing voice dominated the classroom; a collective voice now presides over teaching and learning. Where once monolingualism constrained instruction, now multiple languages and their varieties are employed in the process of co-constructing disciplinary knowledge. Thus, the classroom becomes a context where developing new kinds of identities through the linguistic display of disciplinary knowledge does not represent a threat to the co-existence and the validation of often marginalized language practices relegated to the deficit classroom corner. 


\section{Conclusion}

Equity and access to higher education is fostered under the assumption that all students -emergent bilinguals, non-emergent bilinguals- own the academic discourse that will guarantee their success when navigating the K-16 educational system. In the era of new standards, teachers are called to support all students, including emergent bilinguals, to access and learn the language and discourse practices embedded in their subject areas. The language and literacy demands of the CCSSM and PtA call on secondary mathematics teachers to acquire critical habits of mind and pedagogical action beyond the technical aspects of scaffolding language and learning (e.g., identifying language demands in standards; formulating aligned and relevant content and language objectives; providing sentence and discourse frames to scaffold language and learning, as demonstrated in figure 1). Yet, as $21^{\text {st }}$ century schools exhibit greater diversity, fostering an inclusive classroom culture of discourse for enabling these processes necessarily becomes a more challenging undertaking. Secondary mathematics educators, who generally tend not to consider themselves as "language teachers," need to be prepared to meet the needs of a full range of students with different levels of language proficiency who also may exhibit variability in the use of non-dominant language forms.

In this article, we have argued that fostering a "classroom culture of discourse" in linguistically diverse mathematics high school classrooms requires that teachers become well-versed in pedagogical language knowledge (Bunch, 2013; Galguera, 2011). Beyond facilitating courses where future mathematics teachers acquire an understanding of the technical aspects of scaffolding language and learning (as exemplified in Figure 1), emphasis on the acquisition of pedagogical language knowledge will lead teachers to deeper and practical understandings of the role of language and discourse in (a) the mathematics knowledge construction process, and (b) the teaching and learning of mathematical literacy in linguistically diverse settings. Ultimately, engaging principles and practices in pedagogical language knowledge will help teachers understand how "language exchanges embody diverse social, political, cultural, and socioeconomic positions" (Wagner et al., 2012, p. 87) and to become adept at facilitating democratic classroom engagements where all voices and identities are encouraged and validated. At the same time, these practices will provide students with opportunities to acquire, develop, and display new disciplinary ways of being and knowing. With this in mind, we make a call to mainstream teacher preparation programs to implement mathematics teacher education courses that infuse the tool of pedagogical language knowledge and provide the skills and dispositions to guarantee implementation of a democratic classroom culture of discourse; a fundamental approach to teaching and learning mathematics in linguistically diverse classroom communities.

\section{Acknowledgements}

This research was made possible by the support of the Math \& Science Teacher Initiative (MSTI) at San Diego State University (SDSU).

The author would like to thank the anonymous reviewers for their valuable suggestions for improving the manuscript. 


\section{References}

Aalto, E., \& Tarnanen, M. (2015). Approaching pedagogical knowledge through student teachers: Assessment of second language learners. Language and Education, 29, 400-415. doi:10.1080/09500782.2015.1031676

Aguirre, J. M. (2016). Addressing deficit language in math methods. In D. White, S. Crespo, \& M. Civil (Eds.), Cases for mathematics teacher educators: Facilitating conversations about inequities in mathematics classrooms (pp. 13-21). Charlotte, NC: Information Age.

Alim, S. H. (2005). Critical language awareness in the United States: Revisiting issues and revisiting pedagogies in a resegregated society. Educational Researcher, 34(7), 24-31. doi: $10.3102 / 0013189 \times 034007024$

Aquino-Sterling, C. (2014). Speaking and listening in a new key: Discursive performances in light of Common Core. Voices from the Middle, 22(1), 30-35.

Baugh, J. (1999). Out of the mouths of slaves: African American language and educational malpractice. Austin, TX: University of Texas Press.

Beaudrie, S. (2015). Instructional effectiveness in the SHL classroom: Comparing teacher and student perceptions. Journal of Hispanic Higher Education, 14(3), 274-297. doi: $10.1177 / 1538192715575372$

Bennett, C. A. (2014). Creating cultures of participation to promote mathematical discourse. Middle School Journal, 46(2), 20-25. doi:10.1080/00940771.2014.11461906

Bunch, G. (2013). Pedagogical language knowledge: Preparing mainstream teachers for English learners in the new standards era. Review of Research in Education, 37, 298-341. doi:10.3102/0091732x12461772

Bunch, G., Kibler, A., \& Pimentel, S. (2013). Realizing opportunities for English learners in the Common Core English language arts and disciplinary literacy standards. Retrieved from http:/ / ell.stanford.edu/

Cazden, C. (2001). Classroom discourse: The language of teaching and learning. Portsmouth, NH: Heinemann.

Civil, M. (2002). Culture and mathematics: A community approach. Journal of Intercultural Studies, 23, 133-148. doi:10.1080/07256860220151050a

Constantino, R. (1994). A study concerning instruction of ESL students comparing all-English classroom teacher knowledge and English as a second language teacher knowledge. Journal of Educational Issues of Language Minority Students, 13, 37-57.

Council of Chief State School Officers. (2012). Framework for English language proficiency development standards corresponding to the Common Core State Standards and Next Generation Science Standards. Washington, D.C.: Author.

Crespo, S. (2016). Why are you asking for these impossible math lessons? In D. White, S. Crespo, \& M. Civil (Eds.), Cases for mathematics teacher educators: Facilitating conversations about inequities in mathematics classrooms (pp. 63-69). Charlotte, NC: Information Age.

De Jong, E., \& Harper, C. (2008). ESL is good teaching “plus”: Preparing standard curriculum teachers for all learners. In M. E. Brisk (Ed.), Language, culture, and community in teacher education (pp. 127 - 147). New York: Lawrence Erlbaum.

Delpit, L. (2012). "Multiplication is for white people": Raising expectations for other people's children. New York: The New Press. 
Dimitriades, G., \& McCarthy, C. (2015). Reading and teaching the postcolonial: From Baldwin to Basquiat and beyond. New York: Teachers College Press.

Discourse. (2013). In Merriam-Webster.com. Retrieved from http://www.merriamwebster.com/dictionary/discourse

Duff, P. A. (2010). Language socialization into academic discourse communities. Annual Review of Applied Linguistics, 30, 169-192. doi:10.1017/s0267190510000048

Duff, P. A., \& Talmy, S. (2011). Language socialization approaches to second language acquisition: Social, cultural, and linguistic development in additional languages. In D. Atkinson (Ed.), Alternative approaches to second language acquisition (pp. 95-116). New York: Routledge.

Fang, Z., \& Schleppegrell, M. (2010) Disciplinary literacies across the content areas: Supporting secondary reading through functional language analysis. Journal of Adolescent and Adult Literacy, 53(7), 587-597. doi:10.1598/jaal.53.7.6

Fendel, D., Resek, D., \& Alper, L. (1996). Interactive mathematics program: Year 1. Emeryville, CA: Key Curriculum Press.

Freeman, Y., \& Freeman, D. (2015). Research on preparing inservice teachers to work effectively with Emergent Bilinguals. Bingley: Emerald Group.

Freire, P. (1970). Pedagogy of the oppressed. New York: Continuum.

Galguera, T. (2011). Participant structures as professional learning tasks and the development of pedagogical language knowledge among preservice teachers. Teacher Education Quarterly, 38, 85-106.

García, O., \& Kleyn, T. (Eds). (2016). Translanguaging with multilingual students: Learning from classroom moments. New York: Routledge.

Gee, J. P. (2007). Social linguistics and literacies. Ideology in discourses. London: Routledge.

Gibbons, P. (2009). English learners, academic literacy, and thinking: Learning in the challenge zone. Portsmouth, NH: Heinemann.

Giroux, H. A. (2001). Theory and resistance in education: Towards a pedagogy of the opposition. Westport, CT: Asor Books.

Goldenberg, C. (2008). Teaching English language learners: What the research does -and does not - say. American Educator, 32(2), 42-44.

González, N., Andrade, R., Civil, M., \& Moll, L. C. (2001). Bridging funds of distributed knowledge: Creating zones of practices in mathematics. Journal of Education for Students Placed at Risk, 6, 115-132.

Gutsein, E. (2005). Reading and writing the world with mathematics: Toward a pedagogy for social justice. New York: Routledge.

Hakuta, K. (2013). Constructive classroom conversations: Mastering the language of the Common Core State Standards. Retrieved from https://novoed.com/common-core

Hakuta, K. (2015). Common Core brings language out of the shadows. California Educator, 18(8), 24-25.

Hooks, B. (2010). Teaching critical thinking: Practical wisdom. New York: Routledge.

Lee, O., Quinn, H., \& Valdés, G. (2013). Science and language for English Language Learners in relation to Next Generation Standards and with implications for Common Core 
StateStandards for English language arts and mathematics. Educational Researcher, 42(4), 223-233. doi:10.3102/0013189x13480524

Linquanti, R., \& Hakuta, K. (2012). How Next Generation Science Standards and assessments can foster success for California English learners. Stanford, CA: PACE, Stanford University School of Education.

Mandarino, M., \& Wickens, C. (2014). Addressing disciplinary literacy in the Common Core State Standards. Illinois Reading Council Journal, 42(2), 28-38.

McLaren, P. (2000). Che Guevara, Paulo Freire, and the pedagogy of revolution. Lanham, MD: Rowman and Littlefield.

Menken, K. (2012). Emergent bilingual students in secondary school: Along the academic language and literacy continuum. Language Teaching, 46(4), 438-476. doi: $10.1017 / \mathrm{s} 0261444813000281$

Mills, S. (2004). Discourse. London: Routledge.

Moje, E. B. (2011). Developing disciplinary discourses, literacies, and identities: What's knowledge got to do with it? In G. L. Bonilla, \& K. Englander (Eds.), Discourses and identities in contexts of educational change: Contributions from the United States and Mexico. New York: Peter Lang.

Moschkovich, J. N. (1999). Supporting the participation of English language learners in mathematical discussions. For the Learning of Mathematics, 19, 11-19.

Moschkovich, J. (2007). Examining mathematical discourse practices. For the Learning of Mathematics, 27(1), 24-30.

Moschkovich, J. (2012). Mathematics, the Common Core, and language: Recommendations for mathematics instruction for ELs aligned with the Common Core. Retrieved from http://ell.stanford.edu/

Moschkovich, J. (2016). Hearing mathematical competence expressed in emergent language. In D. White, S. Crespo, \& M. Civil (Eds.), Cases for mathematics teacher educators: Facilitating conversations about inequities in mathematics classrooms (pp. 161-170). Charlotte, NC: Information Age.

National Council of Teachers of Mathematics. (2000). Principles and standards for school Mathematics. Reston, VA: Author.

National Council of Teachers of Mathematics. (2014). Principles to actions: Ensuring mathematical success for all. Reston, VA: Author.

National Council of Supervisors of Mathematics. (2016). Mathematics education through the lens of social justice: Acknowledgment, actions, and accountability. Retrieved from http://www.todosmath.org/assets/docs2016/2016Enews/3.pospaper16_wtodos_8pp.pdf

National Governors Association and Council of Chief State School Officers. (2010). Common Core State Standards for Mathematics. Common Core State Standards. Washington, DC: NGA Center and CCSSO. Retrieved from http://www.corestandards.org

Nero, S., \& Ahmad, N. (2014). Vernaculars in the classroom: Paradoxes, pedagogy, possibilities. New York: Routledge.

Pennycook, A. (2003). Global Englishes, Rip Slyme, and performativity. Journal of Sociolinguistics, 7(4), 513-533. doi:10.1111/j.1467-9841.2003.00240.x

Quinn, H., Lee, O., \& Valdés, G. (January, 2012). Language demands and opportunities in relation to Next Generation Science Standards for English Language Learners: What teachers need to know. 
Paper presented at the Understanding Language Conference, Stanford, CA. Retrieved from http://ell.stanford.edu/papers

Rodríguez, A., \& Kitchen, R. (2005). Preparing mathematics and science teachers for diverse classrooms: Promising strategies for transformative pedagogy. Mahwah, NJ: Erlbaum.

Rodríguez-Valls, F. (2009). Culturally relevant poetry: Creating esperanza (hope) with stanzas. Multicultural Education, 17(1), 10-13.

Roepke, D., \& Gallagher, K. (2015). Using literacy strategies to teach pre-calculus and calculus. Mathematics Teacher, 108(9), 672-678. doi:10.5951/mathteacher.108.9.0672

Sankey, M., \& St. Hill, R. (2009). The ethics of designing for multimodality: Empowering nontraditional learners. In U. Demiray \& R. Sharma (Eds.), Ethical practices and implications on distance education (pp. 126-155). London: Ideas Group International.

Schleppegrell, M. (2010). Language in mathematics teaching and learning: A research review. In J. N. Moschkovich (Ed.), Language and mathematics education: Multiple perspectives and directions for research. Charlotte, NC: Information Age Publishing.

Shanahan, T., \& Shanahan, C. (2008). Teaching disciplinary literacy to adolescents: Rethinking content area literacy. Harvard Educational Review, 78(1), 40-59. doi:10.17763/haer.78.1.v62444321p602101

Short, D., \& Fitzsimmons, F. (2007). Double the work: Challenges and solutions to acquiring language and academic literacy for adolescent English language learners - A report to Carnegie Corporation of New Tork. Washington, D.C.: Alliance for Excellent Education.

Shulman, L. (1986). Those who understand: Knowledge growth in teaching. Educational Researcher, 15(2), 4-14. doi:10.2307/1175860

Silverstein, M. (1996). Monoglot 'standard' in America: Standardization and metaphors of linguistic hegemony. In D. Brenneis \& R. McCaulay (Eds.), The matrix of language (pp. 284-306). Boulder, CO: Westview Press.

Sommerfeld, M., \& Cobb. P. (2009). Cultivating students' discipline-specific dispositions as acritical goal for pedagogy and equity. Pedagogies: An International Journal, 1(1), 49-57. doi:10.1207/s15544818pedo101_8

Spires, H., Kerkhoff, S., \& Graham, A. (2016). Disciplinary literacy and inquiry: Teaching for deeper content learning. Journal of Adolescent E Adult Literacy, 60(2), 1-11. doi: $10.1002 /$ jaal.577

Tan, M. (2011). Mathematics and science teachers' beliefs and practices regarding the teaching of language in content learning. Language Teaching Research, 15(3), 325-342. doi:10.1177/1362168811401153

Téllez, K., Moschkovich, J., \& Civil, M. (Eds.). (2011). Latinos/as and mathematics education: Research on learning and teaching in classrooms and communities. Charlotte, NC: Information Age.

Understanding Language Initiative. (2012). The purpose of English language proficiency standards, assessments, and instruction in an age of new standards: Policy statement from the understanding language initiative. Stanford, CA: Stanford University.

Valdés, G. (2015). Latin@s and the intergenerational continuity of Spanish: The challenges of curricularizing language. International Multilingual Research Journal, 9(4), 253-273. doi:10.1080/19313152.2015.1086625 
Van Lier, L., \& Walqui, A. (2012, January). Language and the Common Core State Standards. Paper presented at the Understanding Language Conference, Stanford, CA. Retrieved from http://ell.stanford.edu/papers

Wagner, D., Herbel-Eisemann, B., \& Choppin, J. (2012). Inherent connections between discourse and equity in mathematics classrooms. In D. Wagner, B. Herbel-Eisemann, B., J. Choppin, \& D. Pimm (Eds.), Equity in discourse for mathematics education (pp. 1-13). London: Springer.

Wells, G., \& Wells, J. (1984). Learning to talk and talking to learn. Theory into Practice, 23(3), 190-197. doi:10.1080/00405848409543113

Wenger, E. (1999). Communities of practice: Learning, meaning, and identity. Cambridge: Cambridge University Press.

White, D., Crespo, S., \& Civil, M. (2016). Cases for mathematics teacher educators: Facilitating conversations about inequities in mathematics classrooms. Charlotte, NC: Information Age.

Xiong, P. (n.d.). Can I be a multicultural educator in math? Retrieved from http://www.nameorg.org/learn/can_i_be_a_multicultural_educa.php

Zahner, W. (2015). The rise and run of a computational understanding of slope in a conceptually focused bilingual algebra class. Educational Studies in Mathematics, 88(1), 19-41. doi:10.1007/s 10649-014-9575-x

Zahner, W., \& Moschkovich, J. (2011). Bilingual students using two languages during peer mathematics discussions: ¿Qué significa? Estudiantes bilingües usando dos idiomas en sus discusiones matemáticas: What does it mean? In K. Téllez, J. Moschkovich, \& M. Civil (Eds.), Latinos/as mathematics education: Research on learning and teaching in classrooms and communities (pp. 37-62). Charlotte, NC: Information Age.

Zahner, W., \& Willey, C. (2014). Integrating communication in Common Core mathematics for bilingual students. In E. Turner and M. Civil (Eds.), The Common Core State Standards in mathematics for English language learners: Grades K-8 (pp. 51-65). Alexandria, VA: TESOL International Association.

Zentella, A. C. (1997). Growing up bilingual: Puerto Rican children in New York. Oxford: Blackwell.

\section{Brief CV of the authors}

\section{Cristian Aquino-Sterling}

Assistant Professor in the School of Teacher Education at San Diego State University. His research addresses two interrelated areas where language and discourse are seen as central elements of K-12 teachers' pedagogical practice: (a) language demands of educational standards and implications for teacher preparation and the education of K12 students in multilingual school contexts; and (b) the assessment and development of Pedagogical Language Competencies in the preparation of K-12 teachers. His works have been published in Bilingual Research Journal; International Journal of Language and Linguistics; International Multilingual Research Journal; International Journal of Bilingual Education and Bilingualism; Multicultural Perspectives; Reading in a Foreign Language, and Voices from the Middle. ORCID ID: 0000-0003-4800-1881. Email: caquino@mail.sdsu.edu 


\section{Fernando Rodríguez-Valls}

Associate Professor at California State University, Fullerton. He has created partnerships with school districts, local educational agencies and universities to develop and implement community-based [bi]literacy programs involving parents and their children in dialogic reading practices that explored the linguistic symmetries between languages -Spanish, English, Catalá and Arabic. He has also developed interdisciplinary curriculum supporting language acquisition for English Learners. Dr. Rodríguez-Valls' work focuses on equitable instructional practices for second language learners and migrant students as well as on the socio-cultural factors affecting their academic achievement, educational continuity and school engagement. ORCID ID: 0000-00016564-6863. Email: frodriguez-valls@exchange.fullerton.edu

\section{William Zahner}

Member of the faculty in the mathematics department at San Diego State University. Zahner's research, teaching, and service activities all focus on how we can improve mathematics learning for all students, especially emergent bilingual students and students from groups underrepresented in science, technology, engineering, and mathematics fields. Zahner taught high school mathematics for six years, including three years in Chuuk, Federated States of Micronesia, and he enjoys teaching mathematics and working with students and teachers from across grade levels K-16. ORCID ID: 0000-0002-2823-0436. Email: bzahner@mail.sdsu.edu 